\title{
Application of Data Mining for Optimal Drug Inventory in a Hospital
}

\author{
Siringo-ringo, Dewi Sahputri \\ Universitas Prima Indonesia \\ Medan, Indonesia \\ dewisahputri.siringoringo@gmail.com \\ Yulizar, Dian \\ Universitas Prima Indonesia \\ Medan, Indonesia \\ dianyulizar3@gmail.com
}

\author{
Tambunan, Razana Baringin Daud \\ Universitas Prima Indonesia \\ Medan, Indonesia \\ razana23tambunan@gmail.com
}

\author{
Daulay, Tri Agustina \\ Universitas Prima Indonesia \\ Medan, Indonesia \\ triagustinadaulay683@gmail.com
}

\author{
Amir Mahmud Husein \\ Universitas Prima Indonesia \\ Medan, Indonesia \\ amirmahmud@unprimdn.ac.id
}

\begin{abstract}
The Hospital is a health care institution that conducts complete individual health services that provide inpatient, outpatient and emergency services. Drug inventory management is one thing that is very important for the survival of hospitals, management of the supply of medical equipment that is not optimal including medicines will have an impact on medical services as well as economically, because $70 \%$ of hospital revenue comes from drugs. In this study we propose data mining with a focus on contributions to the comparison of the K-Means and K-Nearest Neighbor (KNN) algorithms for disease classification, then the classification results are carried out mapping the correlation of diseases with drugs using Apriori, based on the results of testing the K-Means algorithm more accurately compared $\mathrm{KNN}$ in the Apriori method to find the relationship of disease with drugs based on the value of support, trust, support value, trust is expected to be a reference for drug purchase recommendations so that there is no excess or emptiness of the drug.
\end{abstract}

Keywords - datamining; k-means; knn; apriori

\section{INTRODUCTION}

Hospital is a health care institution that organizes individual health services in a plenary that provides inpatient, outpatient, and emergency services (Dep Kes RI, 2016).

The application of data mining in the field of health has been proposed many researchers, because it has the ability to extract large amounts of data to obtain information (Harahap, M et al, 2018).

The classifications are one of the many functions of the data mining process to find an almost identical group of objects (Manuel, Ricky, 2017). A clustering method that has an efficient nature and rapid data processing process one of which is the K-means algorithm. The method of clustering the K-Means, grouping data based on the proximity of data to each other corresponds to the Euclidean distance by comparing the majority of the similarities of other objects assigned to each cluster (Arora \& Shipra, 2015). The study uses 3 classes, many, medium and little. The data used is the medicine sales dataset sourced from the medical record with the gender variable, age category and diagnosis name of the disease.

After performing the Clustering phase, the classification method is also used to find the most disease groups. Classification is a data analysis process that generates a model to describe the classes that exist in the data. There are many types of classification algorithms, two of which are decision trees and $\mathrm{K}$ Nearest Neighbors (KNN). The classification method used is the closest K-Neighbor method, which uses exercise data and data testing (Hermanto, et al, 2019). 
The results of Clustering and classification will be used by the association's rule methods to find links between diseases and medications based on the most 10 diseases. The implementation of the Association rules aims to find information about interconnected items in the form of a rule. Thus the association rules are applied to the most disease data patterns with the medicine using apriori algorithm. Apriori algorithm is a popular algorithm for mining sets of items that often acquire association rules (Rani, 2015).

From the results of the support and confidence obtained from the priori algorithm, this study predicts the medicine needed for the 10 most diseases in optimal inventory.

\section{Literature REVIEW}

\section{A. Data Mining}

Data Mining is the process of converting raw data into data that produces useful and comprehensive information (Arora \& Shipra, 2015).

\section{B. Medical Records}

In regulation of the Minister of Health No. 269/MenKes/PER/III/2008 concerning medical records stating medical records are files containing records and documents in patients containing identity, examination, treatment, other medical measures on Health care services for outpatient and hospitalization, both government and private (Ramadhana, 2019).

\section{Clustering}

Clustering is one of the methods of data processing without direction (without supervision) used in the process of data grouping (Khotimah et al, 2106).

The K-means algorithm is one of the well-known partitioning methods for Clustering. The method of grouping K-means is the grouping of data based on the proximity of data to each other according to the Euclidean distance by comparing the majority of the similarities of other objects assigned to each cluster (Arora \& Shipra, 2015).

\section{Classification}

Classification is the process of data analysis that produces a model to describe the existing classes in the data, this model is called classification (Hermanto et al, 2109).

The K-NN method is a supervised method. At the $\mathrm{KNN}$, the nearby $\mathrm{K}$ neighbors were found for unknown samples and determined the class that had a nearby neighbor. That is, this principle for neighbouring $\mathrm{X}$ closest among the samples is known. KNN can be easily integrated with other machine learning algorithms except lazy learning defects and dependence on class K (Alimjan et al, 2018).

\section{E. Association}

The method of association is one of the data mining techniques in finding combinations or patterns of a set of items. This method is often used in a convenience store sales transaction.

\section{F. Weka Tool}

Weka Tool is the most powerful data mining tool. It is also an open-source tool. It has features such as preprocessing filters, selection, classification and regression, grouping, Discovery Associations, visualizations (Kodati et al, 2019).

\section{Proposed Method}

The methods used in this study are as follows:

\section{A. Clustering Method}

The procedure used to do the grouping using $\mathrm{K}$ means, is as follows:

Select the desired number of k clusters

1. Initialize the center of the cluster $\mathrm{K}$ (centroid) randomly

2. Place each data or object to the nearest cluster. The proximity of two objects is determined by distance. The distance used in the K-means algorithm is Euclidean Distance.

3. Recalculate the cluster center with the current cluster membership. The new cluster Center is the average (mean) of all the data or objects in a specific cluster.

4. Assign again each object by using the new cluster center. If the cluster center does not change anymore, then the processing process is complete. Or, go back to step 3 until the center of the cluster does not change anymore/stabilized or there is no significant decrease of the SSE value (number of squared errors).

\section{B. Classification Method}

The classification method used is $\mathrm{K}$ Nearest Neighbor method which uses training data and testing data.

The KNN algorithm stage is:

1. Specify the K parameter (number of closest neighbors) 
2. Calculate the squared distance from the Euclidean (instance Queri) of each object against the given sample data

3. Then sort the distance into a group that has the smallest Euclid (order result No. 2 ascending)

4. Collecting Y (the classification of nearby neighbors) categories based on the $\mathrm{K}$ value or retrieving neighboring data nearby

5. By using the nearest neighbor category the most majority will result in classification.

\section{Association Method}

The method of association used is a priori algorithm, in which the algorithm seeks support, trust and lifting value. Lifts are a measure of a priori to know the strength of the association rules that have formed.

Stages of the apriori algorithm are:

1. Looking for a support value

2. Analyze in order to determine the data related to each other

3. After all high frequencies are found, the researchers proceed to find an association rule that meets the minimum requirements for confidence by calculating the rules of associations $\mathrm{A}$ and $\mathrm{B}$

4. After getting the result of the support and confidance value, the next step is to look for the lift value. Lifts are a useful measure to know the strength of the association rules that have formed

\section{RESUlt AND Discussion}

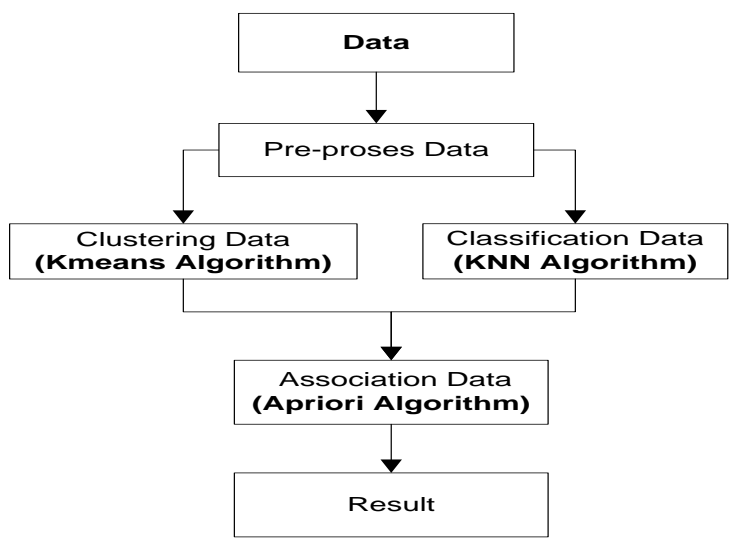

Figure 1. Stages of work process
The Data used is the medicine sales dataset sourced from the medical record at RSU X Medan in 2017. The sales Data of the medicine obtained consists of No. Prescription, patient name, date of sale, patient ID, gender, date of birth, diagnosis code of the patient's disease (ICD-10), diagnosis name of the patient's disease, name of the case type of disease, medicine ID, amount of medicine purchase, medicine price per item and total price of medicine sales With a total of 1041 data in the form of Excel files. The later processed attributes are the diagnose code (ICD$10)$, age and gender categories that have been in preprocess data.

\section{B. Pre-proses Data}

\section{Cleaning Data}

Cleaning data that has incomplete information because the field is empty, or populate the data with a mean value from all data in that column. Because the data that researchers do not have incomplete data then the data cleanup process is not done.

\section{Selection Data}

Grouping attributes after the cleaning data stage.

Table 1. Dataset Grouping

\begin{tabular}{|c|c|c|}
\hline j_k & tgl_lhr & diagnosa_nama \\
\hline male & $2 / 24 / 1940$ & $\begin{array}{l}\text { Diabetes mellitus is not } \\
\text { dependent on insulin }\end{array}$ \\
\hline male & $2 / 24 / 1940$ & $\begin{array}{c}\text { Fluid, electrolyte, and } \\
\text { acid-base disorders }\end{array}$ \\
\hline$\cdot$ & $\cdot$ & $\cdot$ \\
$\cdot$ & $\cdot$ & $\cdot$ \\
$\cdot$ & $\cdot$ & $\cdot$ \\
\hline male & $7 / 19 / 1975$ & Septicemia, unspecified \\
\hline
\end{tabular}

\section{Transformation Data}

The process of initializing data from nominal to numerical can be processed by the KMeans algorithm and the KNN algorithm.

a. Gender

Table 2. Gender Initials

\begin{tabular}{|c|c|}
\hline Gender & Initials \\
\hline Female & 0 \\
\hline Male & 1 \\
\hline
\end{tabular}

b. Birth dates will be grouped into 5 age categories namely infants, toddlers, children, adults and the elderly.

Table 3. Age Category Initials 


\begin{tabular}{|c|c|}
\hline Age Category & Initials \\
\hline Babies & 0 \\
\hline Toddler & 1 \\
\hline Children & 2 \\
\hline Adult & 3 \\
\hline Elderly & 4 \\
\hline
\end{tabular}

c. The name of the diagnosis is obtained from diagnostic data (disease data).

Table 4. Data Initialization Results

\begin{tabular}{|c|c|c|c|}
\hline No & gender & Age_c & diagnosa_nama \\
\hline 1 & 1 & 4 & 2012 \\
\hline 2 & 1 & 4 & 2336 \\
\hline 3 & 0 & 2 & 4288 \\
\hline. &. &. &. \\
\hline. &. &. &. \\
\hline 1041 & 1 & 3 & 226 \\
\hline
\end{tabular}

\section{Pre-process Data}

Save this data as a .csv file. Preprocess data is performed on the Weka 3.8 application by entering the selected data, then the data is stored in a .arrf file which can later be read by Weka.

\section{Clustering Method in Weka}

\section{KMeans Algorithm}

The grouping results obtained from the K-Means Algorithm is:

Full data: 1041 data with 3 attributes

Dengan nilai SSE $=51,17 \%$

The grouping process produces 2 iterations with 417 test data, as follows:

a. cluster 0 (many) there were 223 people or $53 \%$ of 417 records with the number of diseases 77 .

b. cluster 1 (medium) there are 87 people or $21 \%$ of 417 records with 37 diseases.

c. cluster 2 (little) there are 107 people or $26 \%$ of 417 records with the number of diseases 34.

Table 5. Weka K-Means Clustering Results

\begin{tabular}{|c|c|c|c|}
\hline gender & Age_c & diagnose_code & Cluster \\
\hline 0 & 2 & 6 & cluster1 \\
\hline 1 & 4 & 3929 & cluster0 \\
\hline 1 & 4 & 5526 & cluster0 \\
\hline
\end{tabular}

\begin{tabular}{|c|c|c|c|}
\hline$\cdot$ & $\cdot$ & $\cdot$ & $\cdot$ \\
$\cdot$ & $\cdot$ & $\cdot$ & $\cdot$ \\
\hline 1 & 1 & 4340 & cluster0 \\
\hline
\end{tabular}

Table 6. Clustering Analysis Results

\begin{tabular}{|c|c|}
\hline Results Cluster 1 & Results Cluster 2 \\
\hline $\begin{array}{l}\text { Consisting of } 233 \text { people } \\
\text { with a diagnosis of the } \\
\text { diseases: } \\
\text { - Typhoid fever }=11 \\
\text { people } \\
\text { - Diarrhea and } \\
\text { gastroenteritis thought } \\
\text { to be caused by } \\
\text { infection }=8 \text { people } \\
\text { - } \\
\text { - } \text { Chf }+ \text { Pjk }=5 \text { people }\end{array}$ & 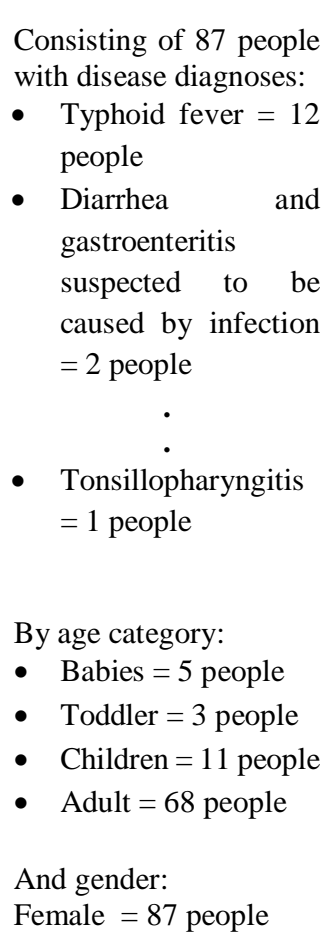 \\
\hline
\end{tabular}

Table 6. Continued

\begin{tabular}{|l|}
\hline \multicolumn{1}{|c|}{ Results Cluster 3} \\
\hline Consisting of 107 people with diagnoses of the \\
disease: \\
- $\quad$ Typhoid fever $=1$ people \\
- Anemia, not specified $=3$ people \\
Chf + Pjk $=4$ people \\
By age category: \\
Elderly $=107$ people \\
And gender: \\
Female $=107$ people
\end{tabular}

\section{Classification Method in Weka}




\section{KNN Algorithm}

The classification results obtained from the KNN method are:

Complete data: 1041 divided into 2 data, namely training data and testing data.

Class classification is divided into 3 parts, namely many, medium and little.

The classification accuracy level is $68 \%$ and the remaining $31 \%$ is the wrong classification.

284 data are classified correctly, while 133 data are not classified correctly.

a. "Many" there are 174 people

b. "Medium" there are 116 people

c. "Little" there are 127 people

Table 7. Results of KNN Classification

\begin{tabular}{|c|c|c|c|c|}
\hline $\mathrm{jk}$ & $\begin{array}{c}\text { k_umu } \\
\mathrm{r}\end{array}$ & d_nama & $\begin{array}{c}\text { p_klasifikas } \\
\mathrm{i}\end{array}$ & $\begin{array}{c}\text { classificatio } \\
\mathrm{n}\end{array}$ \\
\hline 0 & 3 & 3683 & Little & Many \\
\hline 0 & 2 & 6 & Many & Many \\
\hline 0 & 3 & 4267 & Medium & Medium \\
\hline$\cdot$ & $\cdot$ & $\cdot$ & $\cdot$ &. \\
\hline. &. &. &. &. \\
\hline$\cdot$ & $\cdot$ &. &. &. \\
\hline 1 & 3 & 226 & Little & Little \\
\hline
\end{tabular}

Table 8. Results of Prediction Analysis of KNN Classification

\begin{tabular}{|c|c|}
\hline Many & Medium \\
\hline $\begin{array}{l}\text { Consists of } 174 \text { people } \\
\text { with a diagnosis of the } \\
\text { disease: } \\
\text { - Typhoid fever = } 18 \\
\text { people } \\
\text { - Diarrhea and } \\
\text { gastroenteritis } \\
\text { suspected to be caused } \\
\text { by infection = 3 people } \\
\qquad \\
\text { - } \\
\text { Respiratory failure, } \\
\text { unspecification }=1 \\
\text { people }\end{array}$ & $\begin{array}{l}\text { Consisting of } 116 \\
\text { people with a diagnosis } \\
\text { of the disease: } \\
\text { - Typhoid fever = } 1 \\
\text { people } \\
\text { - Diarrhea and } \\
\text { gastroenteritis are } \\
\text { thought to be caused } \\
\text { by infection = } 1 \\
\text { people } \\
\qquad . \\
.\end{array}$ \\
\hline
\end{tabular}

By age Category:

- Toddler $=1$ people $\quad$ By age category:

- Children $=10$ people $\quad$ Babies $=3$ people

- Adult $=66$ people $\quad$ - Children $=3$ people

- Elderly $=97$ people $\quad$ - Adults $=52$ people

- Elderly $=58$ people

And gender:

Female $=86$ people

Male $=88$ people

And gender:

- Female $=42$ people

- Male $=74$ people

Table 8. Continued

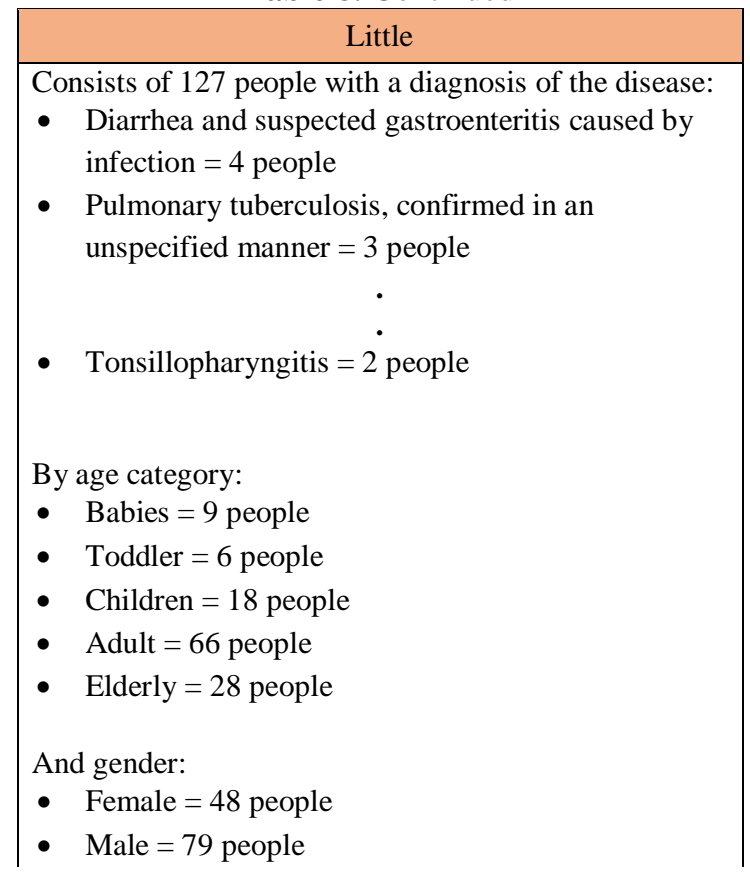

E. Association Method in Rapid Miner

\section{Apriori Algorithm}

The result of the best accuracy of the disease used by the apriori algorithm is the result of the Kmeans algorithm. The disease generated data is found in Table 9, as follows:

Table 9. Most diseases of KMeans algorithm

\begin{tabular}{|c|l|}
\hline ICD-10 & \multicolumn{1}{|c|}{ Name of the disease } \\
\hline J18.0 & Bronkopneumonia, not specified \\
\hline N18.9 & Chronic kidney failure, not specified \\
\hline I50.0 & Congestive heart failure \\
\hline E87.8 & $\begin{array}{l}\text { Electrolyte abnormalities and fluid } \\
\text { balance, not elsewhere classified }\end{array}$ \\
\hline A01.0 & Typhoid fever \\
\hline
\end{tabular}




\begin{tabular}{|c|l|} 
E11.9 & $\begin{array}{l}\text { Diabetes mellitus is not insulin } \\
\text { dependent without complications }\end{array}$ \\
\hline I63.9 & Infark Serebri, not specified \\
\hline A09 & $\begin{array}{l}\text { Diarrhea and Gastroenteritis } \\
\text { suspected to be caused by infection }\end{array}$ \\
\hline I10 & Essential Hypertension (Primary) \\
\hline A91 & Dengue hemorrhagic fever \\
\hline
\end{tabular}

From the above table the researchers describe 10 diseases with medicine and medical devices that are interrelated. Data related to medicine and medical devices are shown in table 10:

Table 10. Medicine and medical devices related to the 10 Most Diseases

\begin{tabular}{|c|c|c|}
\hline ICD-10 & Diagnose name & Medicine name \\
\hline \multirow{11}{*}{ J 18.0} & \multirow{11}{*}{$\begin{array}{l}\text { Bronkopneumonia, } \\
\text { not specified }\end{array}$} & $\begin{array}{l}\text { CEFOTAXIME } 1 \\
\text { GR INJEKSI }\end{array}$ \\
\hline & & $\begin{array}{l}\text { VELUTINE } \\
\text { INJEKSI }\end{array}$ \\
\hline & & $\begin{array}{l}\text { CORTIDEX } \\
\text { INJEKSI }\end{array}$ \\
\hline & & SPUIT $10 \mathrm{CC}$ \\
\hline & & ALCOHOL SWAB \\
\hline & & SPUIT 3 CC \\
\hline & & $\begin{array}{c}\text { MASKER } \\
\text { EARLOOP } \\
(\text { KARET) } \\
\end{array}$ \\
\hline & & $\begin{array}{c}\text { SARUNG } \\
\text { TANGAN NON } \\
\text { STERIL (S) }\end{array}$ \\
\hline & & $\begin{array}{c}\text { CAIRAN 4:1 } \\
\text { WIDA (WIDA D5- } \\
1 / 4 \text { NS) }\end{array}$ \\
\hline & & $\begin{array}{c}\text { 3-WAY BD } \\
\text { CONNECTA PLUS } \\
3 \text { WHITE }\end{array}$ \\
\hline & & $\begin{array}{l}\text { ABBOCATH NO } \\
24 \text { TERUMO }\end{array}$ \\
\hline \multirow{9}{*}{ N 18.9} & \multirow{9}{*}{$\begin{array}{l}\text { Chronic kidney } \\
\text { failure, not specified }\end{array}$} & $\begin{array}{l}\text { INTRAFIX } \\
\text { SAFESET } \\
\text { (DEWASA) }\end{array}$ \\
\hline & & $\begin{array}{l}\text { PHENYTOIN } \\
\text { INJEKSI }\end{array}$ \\
\hline & & $\begin{array}{c}\text { STERIL WATER } \\
1000 \mathrm{ML} \text { OTSU }\end{array}$ \\
\hline & & $\begin{array}{l}\text { RINGER LACTAT } \\
500 \text { ML WIDA }\end{array}$ \\
\hline & & $\begin{array}{c}\text { ONDANSETRON } 4 \\
\text { MG INJEKSI }\end{array}$ \\
\hline & & SPUIT 5 CC \\
\hline & & $\begin{array}{l}\text { NACL } 500 \mathrm{ML} \\
\text { WIDA }\end{array}$ \\
\hline & & $\begin{array}{c}\text { CEFTRIAXONE } 1 \\
\text { GR INJEKSI }\end{array}$ \\
\hline & & $\begin{array}{l}\text { ALLUPURINOL } \\
100 \text { MG TABLET }\end{array}$ \\
\hline
\end{tabular}

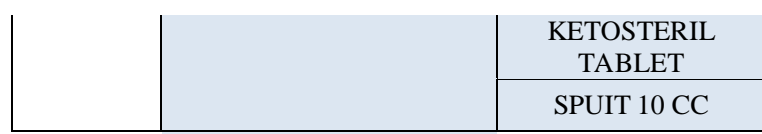

After obtaining medicine that are associated with most diseases, researchers look for a minimum support value of $5 \%$ for 1 itemset candidates, selfconfidence values, and lift values. Here are the results of medicine and medical devices related to most diseases, namely:

Table 11. Medicine results with most diseases

\begin{tabular}{|c|c|c|c|c|}
\hline Diagnosa_N & N_Obat & Sup & Co & Lift \\
\hline \multirow{7}{*}{$\begin{array}{l}\text { Bronkopneu } \\
\text { monia, not } \\
\text { specified }\end{array}$} & $\begin{array}{l}\text { CEFOTAXIME } \\
1 \text { GR INJEKSI }\end{array}$ & 0.2 & 0.5 & $\begin{array}{c}0.62 \\
5 \\
\end{array}$ \\
\hline & SPUIT $10 \mathrm{CC}$ & 0.2 & 0.5 & 0.72 \\
\hline & $\begin{array}{l}\text { ALCOHOL } \\
\text { SWAB }\end{array}$ & 0.2 & 0.5 & 0.84 \\
\hline & SPUIT 3 CC & 0.4 & 0.5 & 1.25 \\
\hline & $\begin{array}{c}\text { MASKER } \\
\text { EARLOOP } \\
\text { (KARET) }\end{array}$ & 0.3 & 0.5 & 1.25 \\
\hline & $\begin{array}{c}\text { SARUNG } \\
\text { TANGAN } \\
\text { NON STERIL } \\
(\mathrm{S})\end{array}$ & 0.3 & 0.5 & 1.25 \\
\hline & $\begin{array}{l}\text { ABBOCATH } \\
\text { NO } 24 \\
\text { TERUMO } \\
\end{array}$ & 0.2 & 0.5 & 2.5 \\
\hline \multirow{8}{*}{$\begin{array}{l}\text { Chronic } \\
\text { kidney } \\
\text { failure, not } \\
\text { specified }\end{array}$} & $\begin{array}{c}\text { RINGER } \\
\text { LACTAT } 500 \\
\text { ML WIDA }\end{array}$ & 0.2 & 0.5 & 0.72 \\
\hline & $\begin{array}{c}\text { ONDANSETR } \\
\text { ON } 4 \text { MG } \\
\text { INJEKSI } \\
\end{array}$ & 0.2 & 0.5 & 0.72 \\
\hline & SPUIT 5 CC & 0.4 & 0.5 & 1 \\
\hline & $\begin{array}{c}\text { CEFTRIAXON } \\
\text { E } 1 \text { GR } \\
\text { INJEKSI }\end{array}$ & 0.2 & 0.5 & $\begin{array}{c}16.6 \\
7\end{array}$ \\
\hline & SPUIT $10 \mathrm{CC}$ & 0.2 & 0.5 & 0.72 \\
\hline & SPUIT 3 CC & 0.4 & 0.5 & 1.25 \\
\hline & $\begin{array}{c}\text { MASKER } \\
\text { EARLOOP } \\
\text { (KARET) }\end{array}$ & 0.3 & 0.5 & 1.25 \\
\hline & $\begin{array}{c}\text { SARUNG } \\
\text { TANGAN } \\
\text { NON STERIL } \\
(\mathrm{S}) \\
\end{array}$ & 0.3 & 0.5 & 1.25 \\
\hline \multirow{4}{*}{$\begin{array}{l}\text { Congestive } \\
\text { heart failure }\end{array}$} & SPUIT $10 \mathrm{CC}$ & 0.2 & 0.5 & 0.72 \\
\hline & SPUIT 3 CC & 0.4 & 0.5 & 1.25 \\
\hline & $\begin{array}{c}\text { MASKER } \\
\text { EARLOOP } \\
\text { (KARET) }\end{array}$ & 0.3 & 0.5 & 1.25 \\
\hline & $\begin{array}{l}\text { SARUNG } \\
\text { TANGAN }\end{array}$ & 0.3 & 0.5 & 1.25 \\
\hline
\end{tabular}




\begin{tabular}{|c|c|c|c|c|}
\hline & $\begin{array}{l}\text { NON STERIL } \\
(\mathrm{S})\end{array}$ & & & \\
\hline & SPUIT 5 CC & 0.4 & 0.5 & 1 \\
\hline & $\begin{array}{c}\text { RANITIDINE } \\
25 \mathrm{MG} \\
\text { INJEKSI }\end{array}$ & 0.2 & 0.5 & 0.84 \\
\hline \multirow{5}{*}{$\begin{array}{l}\text { Electrolyte } \\
\text { abnormalitie } \\
\text { s and fluid } \\
\text { balance, not } \\
\text { elsewhere } \\
\text { classified }\end{array}$} & $\begin{array}{c}\text { SARUNG } \\
\text { TANGAN } \\
\text { NON STERIL } \\
\text { (M) }\end{array}$ & 0.2 & 0.5 & 2.5 \\
\hline & SPUIT 5 CC & 0.4 & 0.5 & 1 \\
\hline & $\begin{array}{l}\text { ALCOHOL } \\
\text { SWAB }\end{array}$ & 0.2 & 0.5 & 0.84 \\
\hline & SPUIT 3 CC & 0.4 & 0.5 & 1.25 \\
\hline & $\begin{array}{l}\text { MASKER } \\
\text { EARLOOP } \\
\text { (KARET) }\end{array}$ & 0.3 & 0.5 & 1.25 \\
\hline \multirow{6}{*}{$\begin{array}{l}\text { Typhoid } \\
\text { fever }\end{array}$} & SPUIT $10 \mathrm{CC}$ & 0.2 & 0.5 & 0.72 \\
\hline & $\begin{array}{c}\text { SARUNG } \\
\text { TANGAN } \\
\text { NON STERIL } \\
(\mathrm{S})\end{array}$ & 0.3 & 0.5 & 1.25 \\
\hline & $\begin{array}{c}\text { RINGER } \\
\text { LACTAT } 500 \\
\text { ML WIDA } \\
\end{array}$ & 0.2 & 0.5 & 0.72 \\
\hline & SPUIT 5 CC & 0.4 & 0.5 & 1 \\
\hline & $\begin{array}{c}\text { CEFTRIAXON } \\
\text { E } 1 \text { GR } \\
\text { INJEKSI }\end{array}$ & 0.2 & 0.5 & $\begin{array}{c}16.6 \\
7\end{array}$ \\
\hline & $\begin{array}{c}\text { RANITIDINE } \\
25 \mathrm{MG} \\
\text { INJEKSI } \\
\end{array}$ & 0.2 & 0.5 & 0.84 \\
\hline \multirow{3}{*}{$\begin{array}{l}\text { Diabetes } \\
\text { mellitus is } \\
\text { not insulin } \\
\text { dependent } \\
\text { without } \\
\text { complication } \\
\mathrm{s}\end{array}$} & SPUIT $10 \mathrm{CC}$ & 0.2 & 0.5 & 0.72 \\
\hline & SPUIT 5 CC & 0.4 & 0.5 & 1 \\
\hline & $\begin{array}{c}\text { RANITIDINE } \\
25 \mathrm{MG} \\
\text { INJEKSI }\end{array}$ & 0.2 & 0.5 & 0.84 \\
\hline \multirow{3}{*}{$\begin{array}{l}\text { Infark } \\
\text { Serebri, not } \\
\text { specified }\end{array}$} & SPUIT $10 \mathrm{CC}$ & 0.2 & 0.5 & 0.72 \\
\hline & SPUIT 3 CC & 0.4 & 0.5 & 1.25 \\
\hline & SPUIT 5 CC & 0.4 & 0.5 & 1 \\
\hline \multirow{6}{*}{$\begin{array}{l}\text { Diarrhea and } \\
\text { Gastroenterit } \\
\text { is suspected } \\
\text { to be caused } \\
\text { by infection }\end{array}$} & $\begin{array}{c}\text { RANITIDINE } \\
25 \mathrm{MG} \\
\text { INJEKSI }\end{array}$ & 0.2 & 0.5 & 0.84 \\
\hline & $\begin{array}{c}\text { CEFTRIAXON } \\
\text { E } 1 \text { GR } \\
\text { INJEKSI }\end{array}$ & 0.2 & 0.5 & $\begin{array}{c}16.6 \\
7\end{array}$ \\
\hline & $\begin{array}{c}\text { RINGER } \\
\text { LACTAT } 500 \\
\text { ML WIDA }\end{array}$ & 0.2 & 0.5 & 0.72 \\
\hline & $\begin{array}{c}\text { ONDANSETR } \\
\text { ON } 4 \text { MG } \\
\text { INJEKSI }\end{array}$ & 0.2 & 0.5 & 0.72 \\
\hline & $\begin{array}{c}\text { ALCOHOL } \\
\text { SWAB }\end{array}$ & 0.2 & 0.5 & 0.84 \\
\hline & SPUIT 3 CC & 0.4 & 0.5 & 1.25 \\
\hline
\end{tabular}

\begin{tabular}{|c|c|c|c|c|}
\hline \multirow{6}{*}{$\begin{array}{l}\text { Essential } \\
\text { Hypertensio } \\
\text { n (Primary) }\end{array}$} & SPUIT $10 \mathrm{CC}$ & 0.2 & 0.5 & 0.72 \\
\hline & SPUIT 3 CC & 0.4 & 0.5 & 1.25 \\
\hline & $\begin{array}{l}\text { MASKER } \\
\text { EARLOOP } \\
\text { (KARET) }\end{array}$ & 0.3 & 0.5 & 1.25 \\
\hline & $\begin{array}{c}\text { SARUNG } \\
\text { TANGAN } \\
\text { NON STERIL } \\
(\mathrm{S})\end{array}$ & 0.3 & 0.5 & 1.25 \\
\hline & $\begin{array}{c}\text { ONDANSETR } \\
\text { ON } 4 \text { MG } \\
\text { INJEKSI } \\
\end{array}$ & 0.2 & 0.5 & 0.72 \\
\hline & SPUIT 5 CC & 0.4 & 0.5 & 1 \\
\hline \multirow{8}{*}{$\begin{array}{l}\text { Dengue } \\
\text { hemorrhagic } \\
\text { fever }\end{array}$} & $\begin{array}{c}\text { SARUNG } \\
\text { TANGAN } \\
\text { NON STERIL } \\
(\mathrm{M})\end{array}$ & 0.2 & 0.5 & 2.5 \\
\hline & $\begin{array}{c}\text { RINGER } \\
\text { LACTAT } 500 \\
\text { ML WIDA }\end{array}$ & 0.2 & 0.5 & 0.72 \\
\hline & $\begin{array}{c}\text { ONDANSETR } \\
\text { ON } 4 \text { MG } \\
\text { INJEKSI } \\
\end{array}$ & 0.2 & 0.5 & 0.72 \\
\hline & SPUIT 5 CC & 0.4 & 0.5 & 1 \\
\hline & $\begin{array}{l}\text { ALCOHOL } \\
\text { SWAB }\end{array}$ & 0.2 & 0.5 & 0.84 \\
\hline & SPUIT 3 CC & 0.4 & 0.5 & 1.25 \\
\hline & $\begin{array}{l}\text { MASKER } \\
\text { EARLOOP } \\
\text { (KARET) }\end{array}$ & 0.3 & 0.5 & 1.25 \\
\hline & $\begin{array}{c}\text { SARUNG } \\
\text { TANGAN } \\
\text { NON STERIL } \\
(\mathrm{S})\end{array}$ & 0.3 & 0.5 & 1.25 \\
\hline
\end{tabular}

Medicines and medical devices that will be recommended for future supplies, that is CEFTRIAXONE 1 GR INJEKSI, MASKER EARLOOP (KARET) dan ABBOCATH NO 24 TERUMO.

\section{Conclusion And Suggestion}

\section{A. Conclusions}

1. K-Means algorithm and KNN algorithm can be used to find the 10 most diseases. The results of the algorithm are used by the a priori algorithm to find the relationship of the disease with the medicine, so that it can recommend medicines that will be provided in the future.

2. The best results from the 10 most diseases are from the Clustering KMeans algorithm.

3. As for medicines and medical equipment that will be recommended for future supplies, that is CEFTRIAXONE 1 GR INJEKSI, 


\section{MASKER EARLOOP (KARET) dan ABBOCATH NO 24 TERUMO.}

\section{B. Suggestions}

1. For further research can do a combination comparison with Clustering methods, classifications and different associations to the medicine inventory.

2. For further research can add attributes in the clustering and classification of patient disease data.

\section{REFERENCES}

Alimjan, Gulnaz, et al. 2018. “A New Technique for Remote Sensing Image Classification Based on Combinatorial Algorithm of SVM and KNN." International Journal of Pattern Recognition and Artificial Intelligence, vol. 32, no. 7, pp. 1-23.

Arora, Preeti, and Shipra Varshney. "Analysis of $K$ Means and K-Medoids Algorithm For Big Data." Procedia - Procedia Computer Science, vol. 78, no. December 2015, Elsevier Masson SAS, 2016, pp. 507-12, doi:10.1016/j.procs.2016.02.095.

Dep Kes RI, 2016. Keputusan Menteri Kesehatan Republik Indonesia Tentang Standar Pelayanan Kefarmasian Di Rumah Sakit, Jakarta

Harahap, M., Husein, A. M., Aisyah, S., Lubis, F. R., \& Wijaya, B. A. (2018, April). Mining association rule based on the diseases population for recommendation of medicine need. In Journal of Physics: Conference Series (Vol. 1007, No. 1, p. 012017). IOP Publishing.

Hermanto, et al. 2019. Comparison of Naïve Bayes Algorithm, C4.5 and Random Forest for Service Classification Ojek Online. Vol. 3, no. 2.

Husein, A. M., Harahap, M., Aisyah, S., Purba, W., \& Muhazir, A. (2018, March). The implementation of two stages clustering (kmeans clustering and adaptive neuro fuzzy inference system) for prediction of medicine need based on medical data. In Journal of Physics: Conference Series (Vol. 978, No. 1, p. 012019). IOP Publishing.

Khotimah, Bain Khusul, et al. 2016. A Genetic Algorithm for Optimized Initial Centers K-
Means Clustering in SMEs. Journal of Theoretical and Applied Information Technology, vol. 90, no. 1, pp. 23-30.

Kodati, Sarangam, et al. 2019. Soft Computing and Signal Processing. Vol. 898, Springer Singapore.

Manuel, Ricky. 2017. Analisa Penentuan Skala Prioritas Obat Berdasarkan Klaster Penyakit Menggunakan Fuzzy C-Means (Studi Kasus : Kecamatan Sirimau Kota Ambon).

Ramadhana, Fanny. 2019. Klasifikasi Data Rekam Medis Berdasarkan International Statistical Classification of Diseases and Related Health Problem (ICD-10) Menggunakan Algoritma K-Nearest Neighbor (K-NN).

Rani, Nisha. 2015. Improving the Performance of Apriori Algorithm by Combining with Clustering Techniques. Vol. 3, no. 2, pp. 1315. 